Ethiopian Journal of Environmental Studies \& Management 8(6): 692 - 707, 2015.

ISSN:1998-0507

doi: http://dx.doi.org/10.4314/ejesm.v8i6.8

Submitted: May 03, 2015

Accepted: September 07, 2015

\title{
BRIQUETTING CHARACTERISTICS OF SOME AGRICULTURAL RESIDUES USING STARCH AS A BINDER
}

\author{
ALHASSAN, E.A. AND *OLAOYE, J.0. \\ Department of Agricultural and Biosystems Engineering Department, University of Ilorin, \\ Ilorin, Nigeria
}

\begin{abstract}
Briquetting of some agricultural wastes was carried out with the construction of a simple briquetting apparatus and using a $3 \times 5$ factorial design the effect of mix ratios (40:60; 50:50 and 60:40) and pressures (10,15,20, 25 and $30 \mathrm{MPa}$ ) on the durability of the briquettes formed was investigated using starch as a binder. The investigation involved the determination of some physical properties, such as moisture content, bulk density and size distribution. The construction and testing of briquette apparatus for making sample briquettes and tumbling formed was carried out so as to evaluate their mechanical performance. It was observed that the mix ratio has a significant influence on the briquettes formed and a highest durability of $89.97 \%$ was observed for saw dust at 25 MPa using a mix ratio of 40: 60 (Material: Binder) and least was 37.30\% for sorghum residues, mix ratio 60: 40 at $10 \mathrm{MPa}$. Consequently, the relaxed and final compaction lengths of the briquette were observed to depend on the mix ratio, applied pressure and nature of the material. A SPSS 16.0 software package was used for briquette durability statistical analysis at $5 \%$ level of confidence. The results of the investigation clearly indicated the value of the applied pressure in producing briquette of the highest durability for each of the material tested. The variation in the mix ratio of the material to binder provided significant deduction to confirm that best condition of materials and binder mix ratio must be set out to ensure production of durable briquettes. These are parameters of interest to the briquette producers for highest productivity and burning efficiency of the briquette to be produced.
\end{abstract}

Key Words: Briquettes, Agricultural Residues, Binders, Mix Ratio

\section{Introduction}

Many of the developing countries produce huge quantities of agro residues but they are used inefficiently causing extensive pollution to the environment (Olaoye, 2001; Koopmans and Koppejan, 1997; Shah et al., 1989; Sambo, 2009; Abila, 2009). The major residues are rice husk, coffee husk, coir pith, jute sticks, bagasse, groundnut shells, mustard stalks and cotton stalks. Sawdust, a milling residue is also available in huge quantity. Apart from the problems of transportation, storage, and handling, the direct burning of loose biomass in conventional grates is associated with very low thermal efficiency and widespread air pollution. The conversion efficiencies are as low as $40 \%$ with particulate emissions in the flue gases in excess of $3000 \mathrm{mg} / \mathrm{Nm}^{3}$. In addition, a large percentage of unburnt carbonaceous ash has to be disposed off (Vimal, 1979;

*Corresponding author: Olaoye, J.O.

Email: jolanoye@unilorin.edu.ng 
Sambo and Doyle, 1986). Briquetting of these materials could mitigate pollution problems while at the same time making use of this important industrial/domestic energy resource.

Biomass briquetting is the densification of loose biomass material to produce compact solid composites of different sizes with the application of pressure. Briquetting of residues takes place with the application of pressure, heat and binding agent on the loose materials to produce the briquettes. Briquetting of agro residues and their utilization will help to reduce pressure on fuel wood and charcoal production, hence reduction in deforestation. According to Olaoye (2001) densified fuels are easy to handle, transport and store, uniform in size and quality, a means to help solve the residue disposal problem. Burning it minimized indoor air pollution. Briquettes is a promising fuel because there is no sulphur and fly ash in it, has high burning efficiency, and are ideally sized for complete combustion. It is easy to ignite with continuous and long burning duration. The briquettes can be used for domestic purposes (cooking, heating, barbequing) and industrial purposes (agro-industries, food processing) in both rural and urban areas.

Historically, biomass briquetting technology has been developed in two distinct directions. Europe and the United States has pursued and perfected the reciprocating $\mathrm{ram} /$ piston press while Japan has independently invented and developed the screw press technology. Although both technologies have their merits and demerits, it is universally accepted that the screw pressed briquettes are far superior to the ram pressed solid briquettes in terms of their storability and combustibility (USDA, 2010). Although the importance of biomass briquettes as substitute fuel for wood, coal and lignite is well recognized, the numerous failures of briquetting machines in almost all developing countries have inhibited their extensive exploitation. Briquetting technology is yet to get a strong foothold in many developing countries because of the technical constraints involved and the lack of knowledge to adapt the technology to suit local conditions (Waelti and Dobie, 1973).

Overcoming the many operational problems associated with this technology and ensuring the quality of the raw material used are crucial factors in determining its commercial success. In addition to this commercial aspect, the importance of this technology lies in conserving wood, a commodity extensively used in developing countries and leading to the widespread destruction of forests. Biomass densification, which is also known as briquetting of sawdust and other agro residues, has been practiced for many years in several countries. These can be burnt clean and therefore are eco-friendly and also those advantages that are associated with the use of biomass are present in the briquettes.

The objectives of the study were to investigate the characteristics of the briquettes formed from rice husk, rice straw, maize cob, soya bean wastes, saw dust, guinea corn wastes, sugar cane bagasses and combination of these agricultural wastes using starch as a binder. The physical properties of the briquettes formed were investigated. The construction and testing of briquette apparatus were undertaken to evaluate the mechanical performance of the briquettes formed.

\section{Materials and Methods Experimental Materials}

The raw materials to be used for biomass briquetting are: Agricultural residues (maize, sorghum, rice husk and straw, soya bean and sugar cane bagasse.); 
Wood waste product (Sawdust) and Starch. Other items employed for the experiment include mortar and pestle, trowel, plastic bowl, and sack among others. The instrument and other equipment employed for measurement include: Weighing Balance, a Camry emperors capacity $100 \mathrm{~kg} / 220 \mathrm{lbs}$, graduation $200 \mathrm{~g} / 8 \mathrm{oz}$ weighing balance was used for the briquette sample residues measuring. Hydraulic Press of a $70 \mathrm{MPa}$ capacity was used as compressive machine for the densification of the biomass in the mould. A Tumbling Apparatus was the standard apparatus used for determining the durability of briquette formed. Moisture Meter, a standard infrared moisture meter balance was used for determining the moisture content of the sample. Vernier caliper and Ruler were used for the determination of the diameter and length of the briquette formed. A Tyler Sieve, 1910 of $2.36 \mathrm{~mm}$ was used for size determination of the samples and sieve analysis.

\section{Experimental Briquetting Machine}

The briquetting machine, basically a cylindrical die press with some component parts was constructed for this research. It consists of the piston, a $80 \mathrm{~mm}$ diameter cylindrical iron pipe, a $20 \mathrm{~mm}$ pipe that act as mandree to create the internal hole in the briquette, circular plates and a wooden base machined to create the seat for the pipes. The set up was mounted on the frame of the hydraulic press as shown in figures 1 and 2 .

The briquetting apparatus was used for the densification of the crop residues and the binding agent. The $80 \times 150 \mathrm{~mm}$ diameter height of material in the briquetting mould was densified using 10 , $15,20,25$ and $30 \mathrm{MPa}$ applied pressures respectively through the hydraulic press mounted on a frame (Olaoye et al., 2003). The applied pressures were for 20 minutes continuously to obtain desirable briquettes.
Figures 3 and 4 show the orthographic projections, isometric view and assembly drawing of the briquetting apparatus.

Experimental Design for Comparison of Briquettes Formed

The data recorded during the experiment was statistically analyzed using $3 \times 5$ factorial designs to study the effects of the two factors combination of mix ratios and compaction pressures on the change in dimension and durability of the briquettes formed.

Every single trial was replicated three times making a total of 45 samples. The analysis enables in the investigation of the significance effect of the factors as well as the interaction effect (Oyejola, 2003). In addition, there is the need to conduct comparison of means for the significantly different factors. Hence, Duncan's New Multiple Range Test (DNMRT) was carried out in order to compare the durability of the sample at the various mixing ratio and compaction pressures.

\section{Briquette Making Process}

The materials for briquetting are classified into three groups to include the plant residues, binding agent and briquetting apparatus (Olaoye et al., 2003). All were sourced locally and densified in the laboratory accordingly. Having determined the physical properties of the sample to be briquetted, the steps below was followed in making the briquette as stated by Vimal (1979) and Webb (1979):

The residues and binder was separately weighed

Both the residue and binder were mixed in appropriate proportion. The mixed residue and binder was introduced into the briquette mould and filled from a height of $150 \mathrm{~mm}$ without compression (BS 1377). The briquette apparatus was mounted on a hydraulic press for the various pressures for compaction. 
After compression for 20 minutes, the briquetting apparatus was removed from the pressing machine, the plate-like washer was removed and the mandree which help

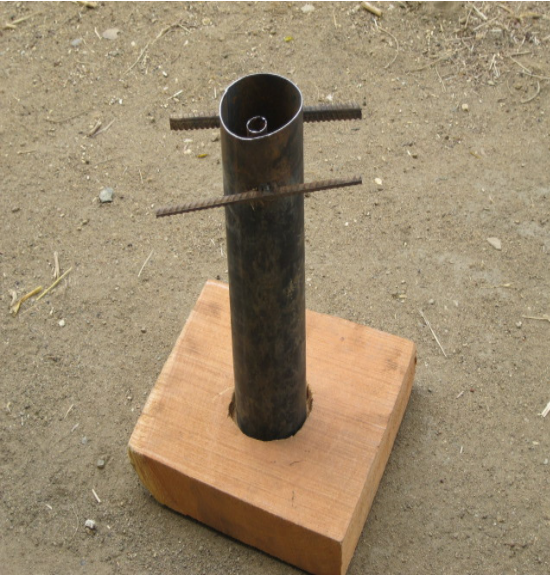

Figure 1: Briquetting Apparatus to create the hole in the briquette, the base separated so as to remove the briquette formed as carefully as possible.
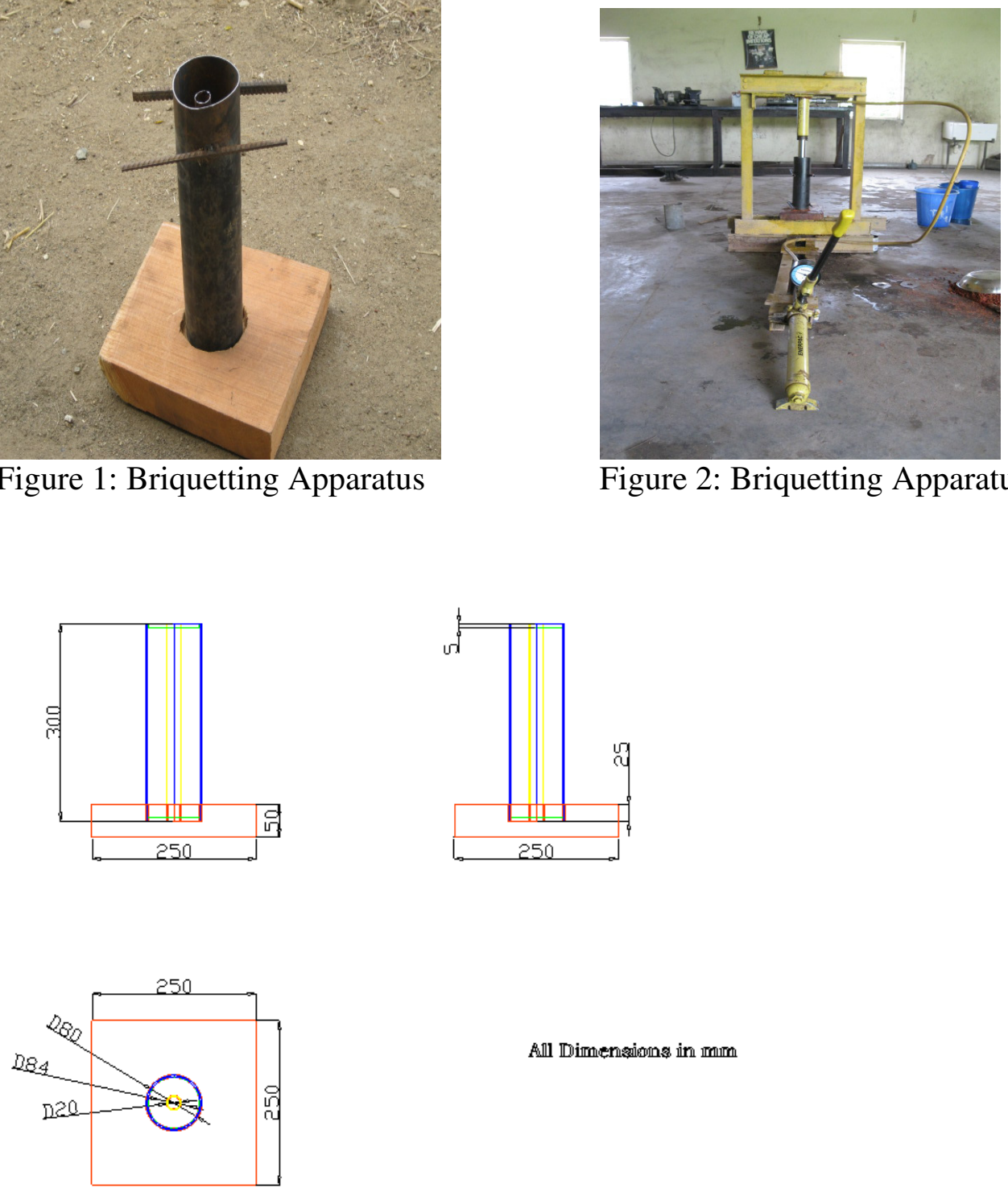

Figure 2: Briquetting Apparatus Set Up

Figure 3: Orthographic projections of the Briquetting Apparatus 

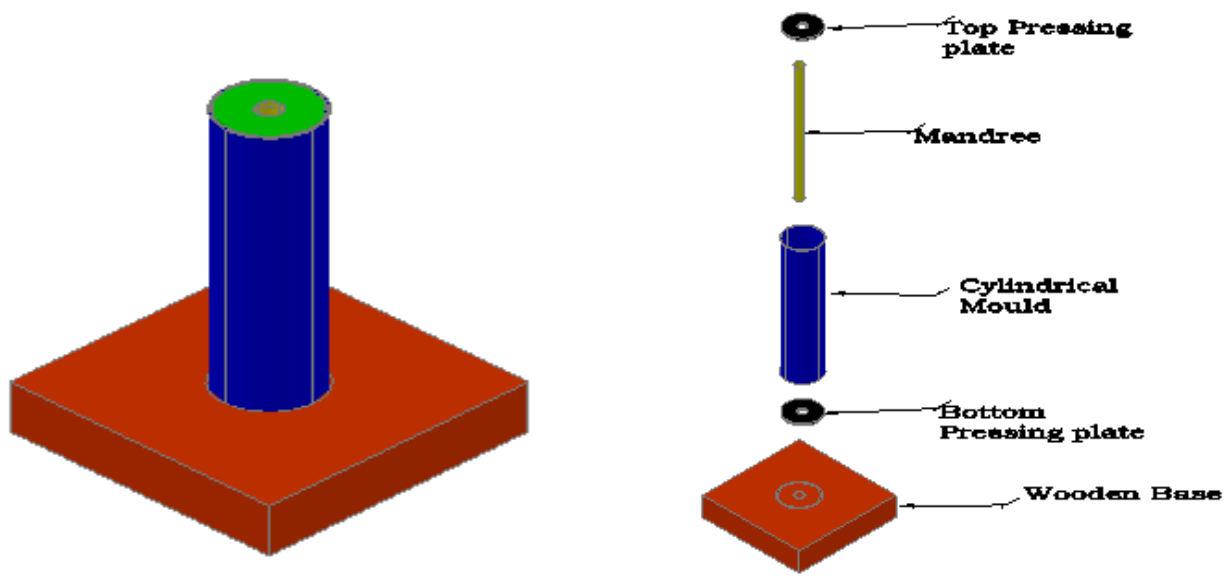

Figure 4: Isometric View and Assembly Drawing of the Briquetting Apparatus

Briquette length was determined immediately the briquette was extracted from the mould and then after 5 minutes interval for the next 30 minutes. The initial length was used as the final compaction length while the increase in length after 30 minutes was used as the relaxed or spring back length of the briquettes

The briquettes formed were labeled according to the mixing proportion and type of constituent materials.

\section{Test Procedure}

Each of the residues sample was mixed with starch in the proportion determined by weight using the weighing balance such that the sample were at a final moisture content irrespective of their initial moisture content. Mixing took place by placing the sample on a cleaned concrete floor, pouring the binder to be used on it, and thoroughly mixing the sample with a hand trowel. The quantity of each sample required for the tests were all mixed at the beginning of the test, results observed and recorded for each operation. Figure 5 shows the biomass briquetting technique used in the experiment.
Sample lost during loading of the mould, transfer of the mould and during the extraction of the briquette were reloaded and recompressed. The broken briquettes during extraction were also reloaded and recompressed. The briquette were placed on a ply wood and allowed to dry for two weeks.

The briquettes formed from the experiment were subjected to these varying tests to determine their physical and mechanical characteristics and properties. These include:

Change in length and diameter: The length of the briquette formed after compaction was determine by the use of a meter rule and the diameter by a vernier caliper.

Durability test: The durability of briquettes was determined by tumbling the test sample for 10 minutes at $15 \mathrm{rpm}$ in a dust tight container. The test was conducted after two weeks of briquette formation. The fines were separated by screening and the ratio of whole briquettes was calculated as follows:

$$
\text { Durability }(\%)=\frac{\text { Mass of Briquette After Tumbling, } \mathrm{kg}}{\text { Mass of Briquette Before Tumbling, } \mathrm{kg}}
$$


Results and Discussion

Some Properties of the Briquette Materials

Table1 shows some physical properties of the materials used for briquette formation. The moisture content of the material ranges from $8.2-9.2 \%$ and the bulk density from $0.06875 \mathrm{~g} / \mathrm{cm}^{3}$ for sugar cane bagasses to $0.3018 \mathrm{~g} / \mathrm{cm}^{3}$ for guinea corn wastes. It is important to establish the initial moisture content of the biomass feed so that the briquettes produced have moisture content greater than the equilibrium value, otherwise the briquettes may swell during storage and transportation and disintegrate when exposed to humid atmospheric conditions.

The two (2) principal factors that were examined on the briquetting of the materials using the briquetting apparatus were the mix ratio and pressure. Tables 2 and 3 present the results of the Analysis of Variance (ANOVA) of the effects these factors on the durability of the briquettes.

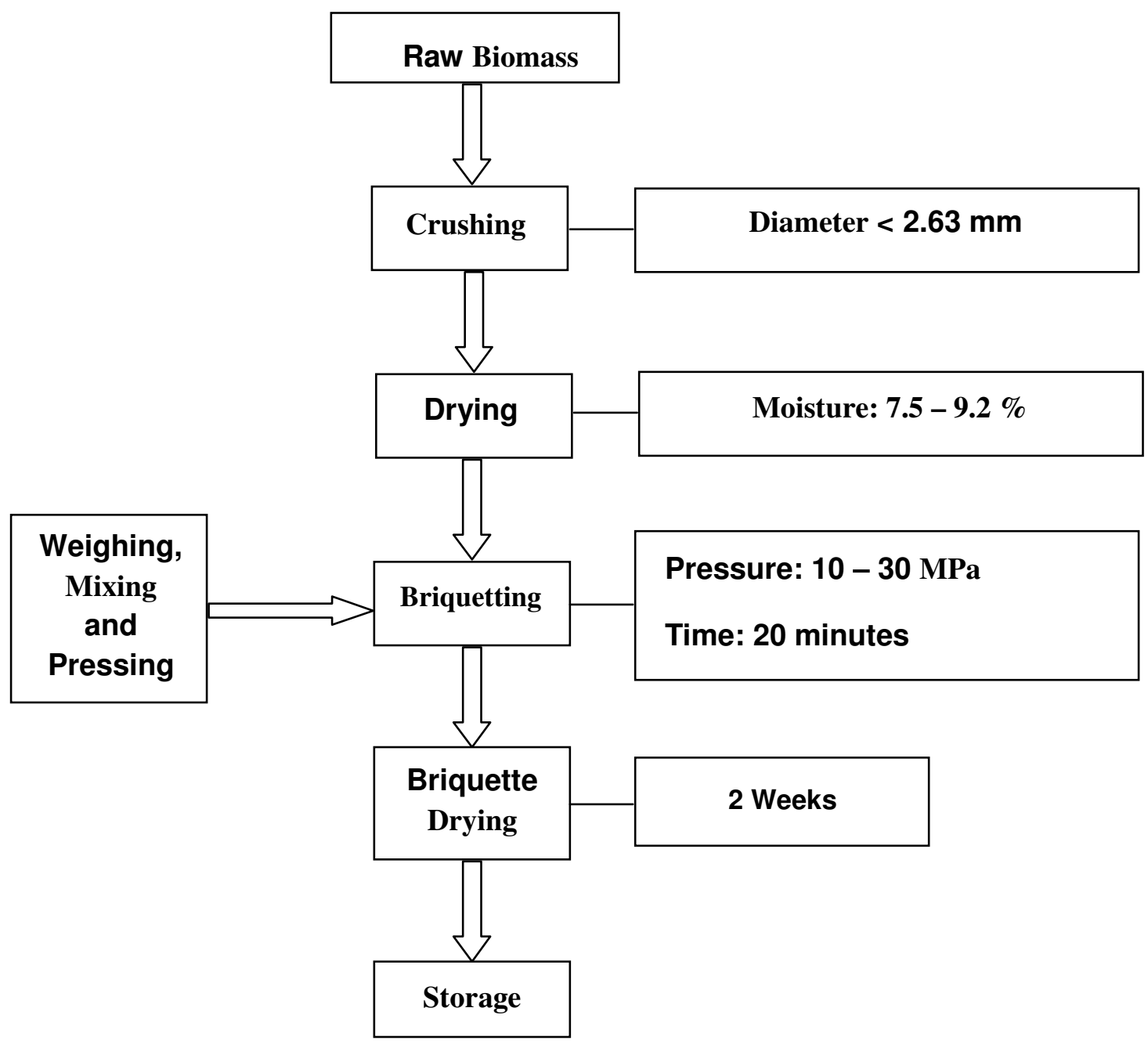

Figure 5 shows the biomass briquetting technique used in the experiment 
Table 1: Property of the Briquette Materials

\begin{tabular}{llll}
\hline S/N & Residues & M/C $(\%)$ & Bulk Density $\left(\mathrm{g} / \mathrm{cm}^{3}\right)$ \\
\hline 1 & Rice Husk & 8.2 & 0.2812 \\
2 & Rice Straw & 7.6 & 0.07945 \\
3 & Maize Cob & 7.5 & 0.2239 \\
4 & Soya Bean Wastes & 7.6 & 0.17335 \\
5 & Saw Dust & 9.2 & 0.2339 \\
6 & Guinea Corn Wastes & 8.5 & 0.3018 \\
7 & Sugar Cane Bagasses & 8.2 & 0.06875 \\
\hline
\end{tabular}

\section{The Effect of Pressure on the Durability} of Briquettes Formed

The results of the statistical analysis of variance of the effect of pressure on the briquette at $5 \%$ significance level ( $\mathrm{F}$ at $5 \%$ ) were presented in table 2 . The effect of the pressure on the briquette durability is significant only for sorghum residues and for the other materials it was not significant. This shows that any variation in pressure does not have direct influence on the briquette durability of these other materials. It was observed that all the applied pressures, produce a stable briquettes and only sorghum has its highest durability of $53.59 \%$ at $30 \mathrm{MPa}$ while the others were at $25 \mathrm{MPa}$. This result was as indicated by Olaoye et al., (2003).

Table 3 shows the mean comparison of the effect of pressure on the durability of sorghum residues. The mean with the same letters are significantly the same while those with different letters are significantly different. This confirmed the results obtained in the durability test of the sorghum residue briquette. The mean for briquettes at pressures of $10,15,20 \mathrm{MPa}$ were not significantly different and those of 20 and $25 \mathrm{MPa}$ are not significantly different and that of 25 and $30 \mathrm{MPa}$. This revealed that higher pressure implies more durable briquette for sorghum residues.

The Effect of Mix Ratio on the Durability of Briquettes Formed

The results of the statistical analysis of variance of the effect of mix ratio on the durability of briquettes formed were presented in table 4 . The table shows that the mix ratio of material to binder has significant effect on the durability of all the materials except for sorghum residues. The result gave an indication that variation in the mix ratio of the material to binder has direct influence on the durability and that best condition must be set out to ensure production of durable briquettes. The importance of the durability test is to be able to select the best condition for production of stable briquette at minimum losses and to preserve the quality of the product during handling and storage. It helps to determine the percentage solid briquette remaining after tumbling in the tumbling apparatus as described. The durability of the briquettes produced varied from $89.97 \%$ at $25 \mathrm{MPa}, 40: 60 \mathrm{mix}$ ratio for saw dust to $37.30 \%$ at $10 \mathrm{MPa}, 60: 40 \mathrm{mix}$ ratio for sorghum residues.

A durability rating of $80-90 \%$ should be considered "good" and $90 \%$ or above "very good" (Waeli et al., 1973 in Olaoye et al., 2003). The mean comparison of the effect of mix ratio on briquettes durability was presented in table 5. Means with the same letter are significantly the same. For all the materials compared, mix ratio of 40:60 and 50:50 are significantly the same. It implies that, these mixing ratios will produce a durable briquette.

Applied Pressures and Relaxed or Spring Back Lengths for Given Mix Ratios of Briquette Formed

Figures 6 to 12 show the effects of applied pressures on the relaxed length of 
the briquette for a given mix ratio after removal from the mould. The trends of curves exhibited by the set of curves are relatively the same. The relaxed length tends to reduce at higher compressive pressure. Hence increase in applied pressure irrespective of the mix ratio and the material leads to reduction in relaxed length. Irrespective of the material, the samples with mix ratio of 40:60 (material: binder) have the least relaxed length; while samples with mixing ratio of 60:40 have the highest relax length.

Table 2: Analysis of Variance of the Effect of Applied Pressure on the Durability of Briquettes

\begin{tabular}{|c|c|c|c|c|c|c|}
\hline Material & $\begin{array}{l}\text { Sources of } \\
\text { Variation }\end{array}$ & S.S & d.f & M.S & $\mathrm{F}$ & Sig. \\
\hline \multirow[t]{3}{*}{ Saw Dust } & Between Groups & 363.556 & 4 & 90.889 & 1.426 & 0.295 \\
\hline & Within Groups & 637.365 & 10 & 63.737 & & \\
\hline & Total & 1000.922 & 14 & & & \\
\hline \multirow[t]{3}{*}{ Rice Husk } & Between Groups & 231.545 & 4 & 57.886 & 1.377 & 0.310 \\
\hline & Within Groups & 420.419 & 10 & 42.042 & & \\
\hline & Total & 651.964 & 14 & & & \\
\hline \multirow[t]{3}{*}{ Sugar Cane bagasses } & Between Groups & 211.567 & 4 & 52.892 & 1.263 & 0.347 \\
\hline & Within Groups & 418.712 & 10 & 41.871 & & \\
\hline & Total & 630.279 & 14 & & & \\
\hline \multirow[t]{3}{*}{ Maize Cob } & Between Groups & 229.285 & 4 & 57.321 & 1.895 & 0.188 \\
\hline & Within Groups & 302.505 & 10 & 30.250 & & \\
\hline & Total & 531.790 & 14 & & & \\
\hline \multirow[t]{3}{*}{ Sorghum Residues } & Between Groups & 298.730 & 4 & 74.682 & 10.714 & 0.001 \\
\hline & Within Groups & 69.706 & 10 & 6.971 & & \\
\hline & Total & 368.436 & 14 & & & \\
\hline \multirow[t]{3}{*}{ Soya bean Residues } & Between Groups & 194.901 & 4 & 48.725 & 1.231 & 0.358 \\
\hline & Within Groups & 395.795 & 10 & 39.580 & & \\
\hline & Total & 590.696 & 14 & & & \\
\hline \multirow[t]{3}{*}{ Rice Straw } & Between Groups & 161.371 & 4 & 40.343 & 1.487 & 0.278 \\
\hline & Within Groups & 271.267 & 10 & 27.127 & & \\
\hline & Total & 432.638 & 14 & & & \\
\hline
\end{tabular}

Table 3: Duncan's New Multiple Range Test for the Effect of Pressure on Sorghum Residues Durability*

\begin{tabular}{ccccc}
\hline Pressure & N & Subset for $\alpha=\mathbf{0 . 0 5}$ & \\
\hline & & 1 & 2 & 3 \\
10 & 3 & $40.60^{\mathrm{a}}$ & & \\
15 & 3 & $41.66^{\mathrm{a}}$ & $45.39^{\mathrm{b}}$ & \\
20 & 3 & $45.39^{\mathrm{a}}$ & $48.94^{\mathrm{b}}$ & $48.94^{\mathrm{c}}$ \\
25 & 3 & & & $52.54^{\mathrm{c}}$ \\
30 & 3 & & & 0.127 \\
Sig & & 0.060 & 0.130 & 0.127 \\
\hline
\end{tabular}

*Values with different letters are significantly different 
Table 4: Analysis of Variance of the Effect of Mixing Ratio on the Durability of Briquettes

\begin{tabular}{|c|c|c|c|c|c|c|}
\hline Material & $\begin{array}{l}\text { Sources of } \\
\text { Variation }\end{array}$ & SS & df & M.S & $\mathrm{F}$ & Sig. \\
\hline \multirow[t]{4}{*}{ Saw Dust } & Between & 624.085 & 2 & 312.042 & 9.937 & 0.003 \\
\hline & $\begin{array}{l}\text { Groups } \\
\text { Within }\end{array}$ & 376.837 & 12 & 31.403 & & \\
\hline & Groups & & & & & \\
\hline & Total & 1000.922 & 14 & & & \\
\hline \multirow[t]{4}{*}{ Rice Husk } & $\begin{array}{c}\text { Between } \\
\text { Groups }\end{array}$ & 417.507 & 2 & 208.754 & 10.684 & 0.002 \\
\hline & Within & 234.457 & 12 & 19.538 & & \\
\hline & Groups & & & & & \\
\hline & Total & 651.964 & 14 & & & \\
\hline \multirow{5}{*}{$\begin{array}{c}\text { Sugar Cane } \\
\text { Bagasses }\end{array}$} & Between & 409.634 & 2 & 204.817 & 11.139 & 0.002 \\
\hline & Groups & & & & & \\
\hline & Within & 220.645 & 12 & 18.387 & & \\
\hline & Groups & & & & & \\
\hline & Total & 630.279 & 14 & & & \\
\hline \multirow[t]{4}{*}{ Maize Cob } & $\begin{array}{l}\text { Between } \\
\text { Groups }\end{array}$ & 285.887 & 2 & 142.943 & 6.976 & 0.010 \\
\hline & Within & 245.903 & 12 & 20.492 & & \\
\hline & Groups & & & & & \\
\hline & Total & 531.790 & 14 & & & \\
\hline \multirow[t]{4}{*}{ Sorghum Residues } & $\begin{array}{l}\text { Between } \\
\text { Groups }\end{array}$ & 36.154 & 2 & 18.077 & .653 & 0.538 \\
\hline & Within & 332.282 & 12 & 27.690 & & \\
\hline & Groups & & & & & \\
\hline & Total & 368.436 & 14 & & & \\
\hline \multirow{5}{*}{$\begin{array}{c}\text { Soya Bean } \\
\text { Residues }\end{array}$} & Between & 389.898 & 2 & 194.949 & 11.650 & 0.002 \\
\hline & Groups & & & & & \\
\hline & Within & 200.798 & 12 & 16.733 & & \\
\hline & Groups & & & & & \\
\hline & Total & 590.696 & 14 & & & \\
\hline \multirow[t]{4}{*}{ Rice Straw } & $\begin{array}{l}\text { Between } \\
\text { Groups }\end{array}$ & 264.226 & 2 & 132.113 & 9.414 & 0.003 \\
\hline & Within & 168.412 & 12 & 14.034 & & \\
\hline & Groups & & & & & \\
\hline & Total & 432.638 & 14 & & & \\
\hline
\end{tabular}


Table 5: Duncan's New Multiple Range Test for the Effect of Mixing Ratio on the Durability of the Briquettes*

\begin{tabular}{|c|c|c|c|c|}
\hline \multirow[b]{2}{*}{ Material } & \multicolumn{4}{|c|}{ Subset for $\alpha=0.05$} \\
\hline & $\begin{array}{c}\text { Mixing } \\
\text { Ratio }\end{array}$ & $\mathrm{N}$ & 1 & 2 \\
\hline \multirow[t]{4}{*}{ Saw dust } & 3 & 5 & 67.38 & \\
\hline & 2 & 5 & & $77.04^{\mathrm{a}}$ \\
\hline & 1 & 5 & & $83.03^{\mathrm{a}}$ \\
\hline & Sign & & 1.000 & 0.117 \\
\hline \multirow[t]{4}{*}{ Rice Husk } & 3 & 5 & 65.10 & \\
\hline & 2 & 5 & & $74.90^{\mathrm{b}}$ \\
\hline & 1 & 5 & & $77.30^{\mathrm{b}}$ \\
\hline & Sign & & 1.000 & 0.409 \\
\hline Sugar Cane & 3 & 5 & 62.53 & \\
\hline \multirow[t]{3}{*}{ Bagasse } & 2 & 5 & & $72.46^{\mathrm{c}}$ \\
\hline & 1 & 5 & & $74.49^{\mathrm{c}}$ \\
\hline & Sign & & 1.000 & 0.469 \\
\hline \multirow[t]{4}{*}{ Maize cob } & 3 & 5 & 53.21 & \\
\hline & 2 & 5 & & $60.92^{\mathrm{d}}$ \\
\hline & 1 & 5 & & $63.49^{\mathrm{d}}$ \\
\hline & Sign & & 1.000 & 0.388 \\
\hline \multirow{4}{*}{$\begin{array}{l}\text { Soya bean } \\
\text { residues }\end{array}$} & 3 & 5 & 61.43 & \\
\hline & 2 & 5 & & $71.10^{\mathrm{e}}$ \\
\hline & 1 & 5 & & $73.11^{\mathrm{e}}$ \\
\hline & Sign & & 1.000 & 0.451 \\
\hline \multirow[t]{4}{*}{ Rice Straw } & 3 & 5 & 59.51 & \\
\hline & 2 & 5 & & $67.69^{f}$ \\
\hline & 1 & 5 & & $68.99^{f}$ \\
\hline & Sign & & 1.000 & 0.592 \\
\hline
\end{tabular}

*Values with same letters are not significantly different

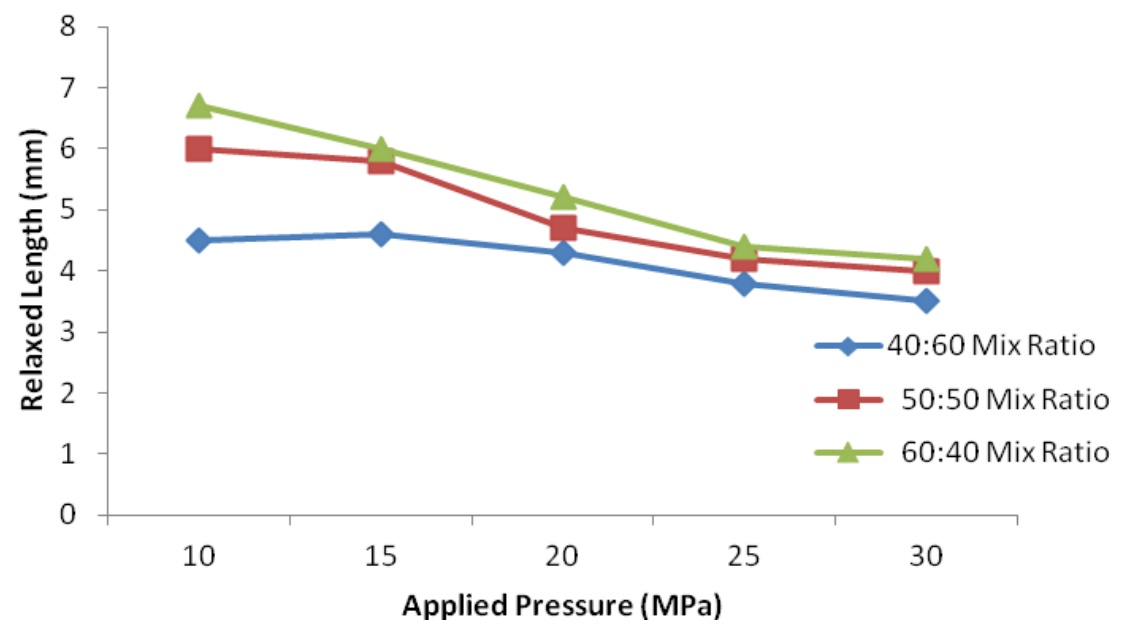

Figure 6: Graph of Applied Pressures Against Relaxed or Spring Back Lengths for Given Mix Ratios for Rice Husk. 


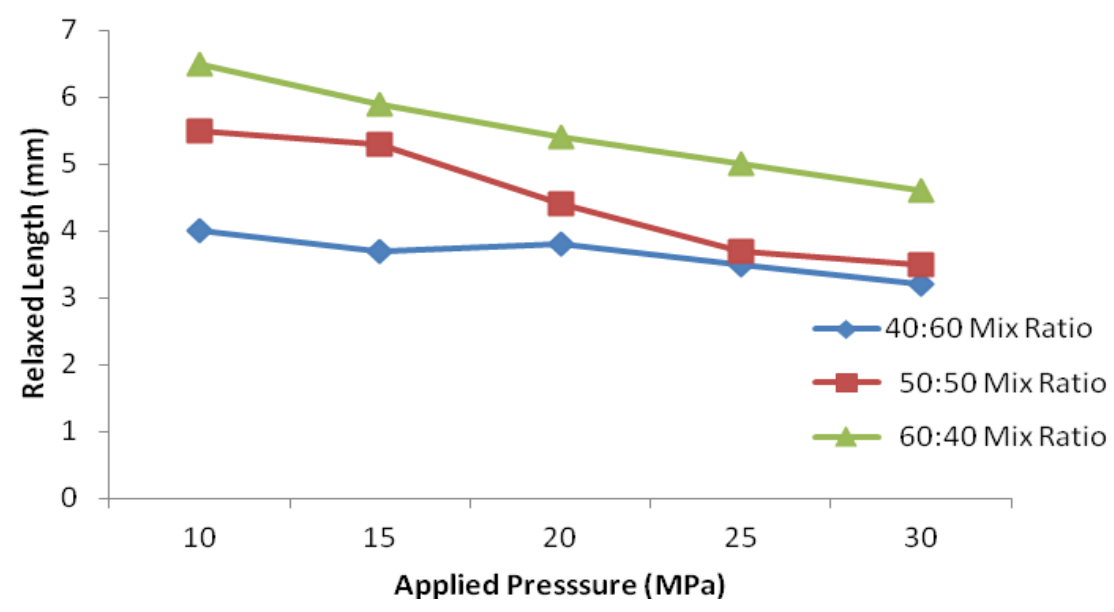

Figure 7: Graph of Applied Pressures Against Relaxed or Spring Back Lengths for Given Mix Ratios for Saw Dust

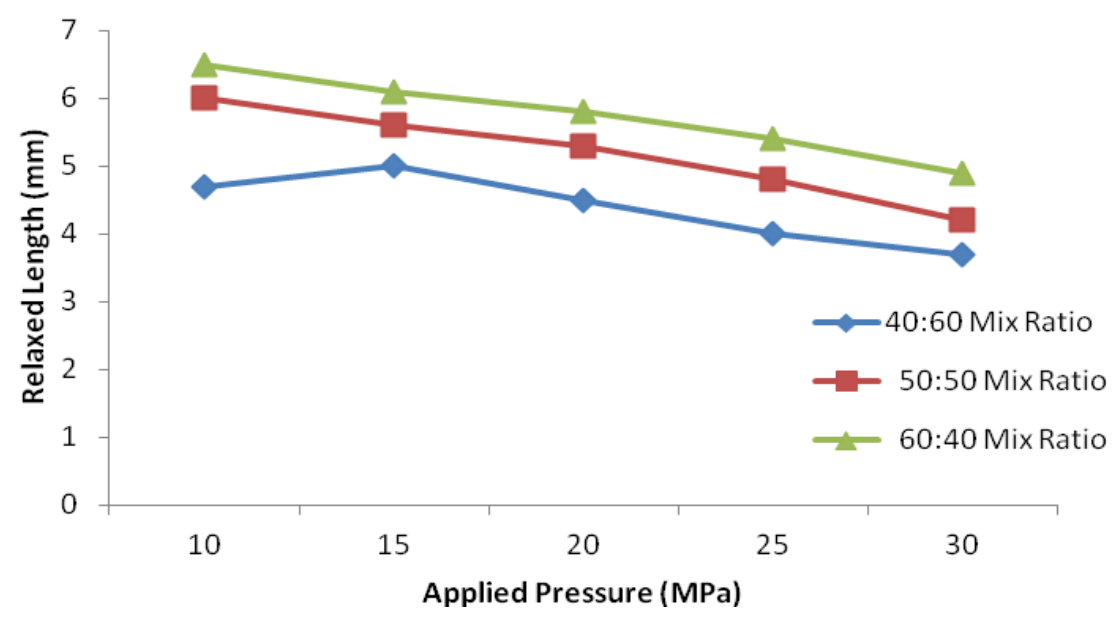

Figure 8: Graph of Applied Pressures Against Relaxed or Spring Back Lengths for Given Mix Ratios for Soya Bean Residues

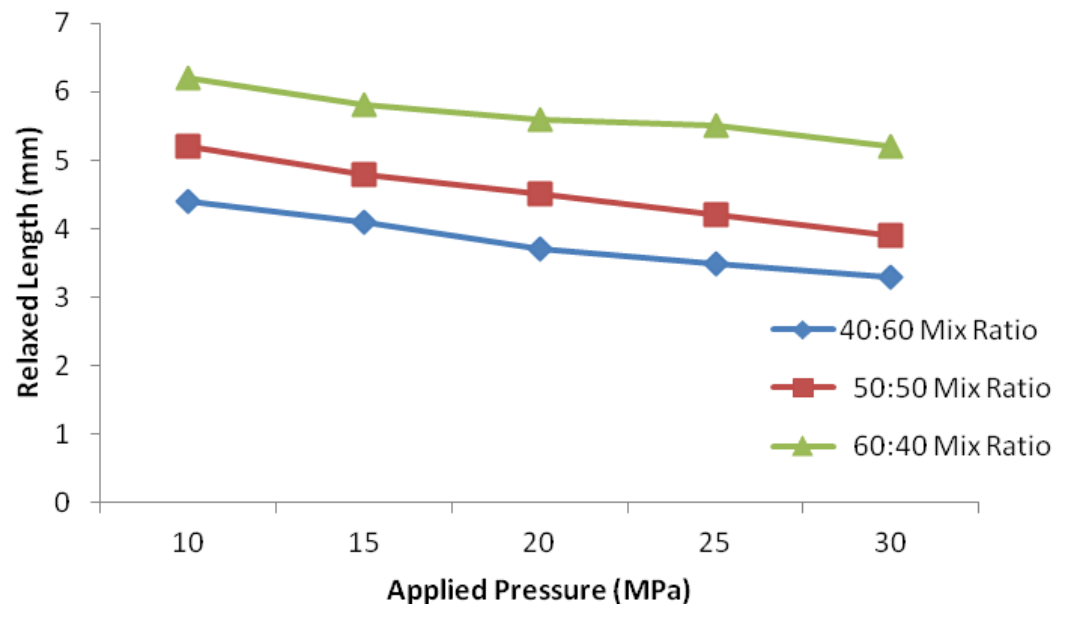

Figure 9: Graph of Applied Pressures Against Relaxed or Spring Back Lengths for Given Mix Ratios for Sugar Cane Bagasses. 


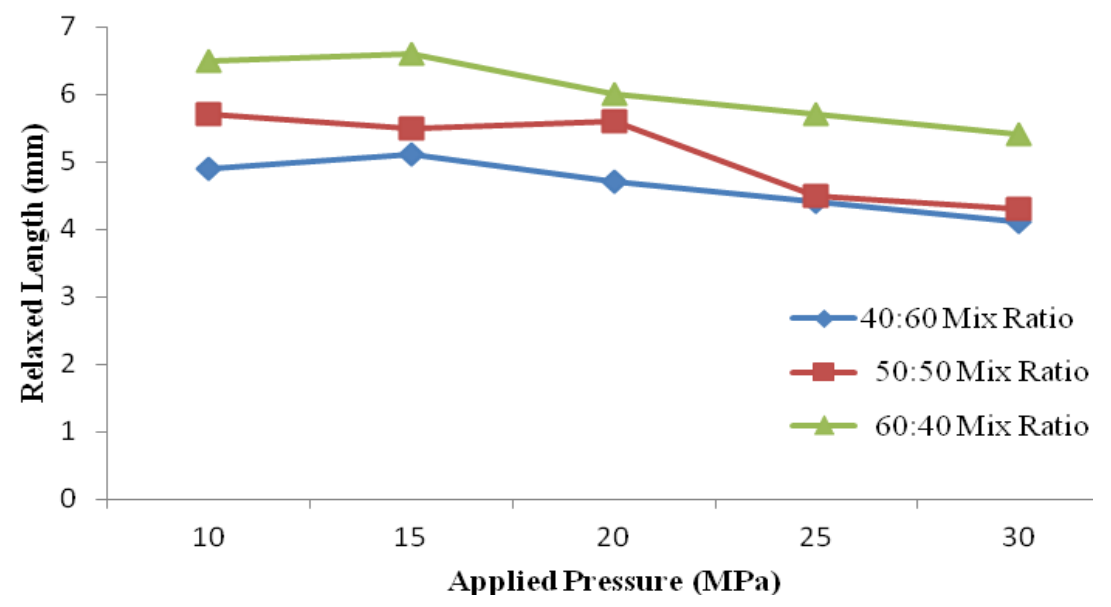

Figure 10: Graph of Applied Pressures Against Relaxed or Spring Back Lengths for Given Mix Ratios for Maize Cob

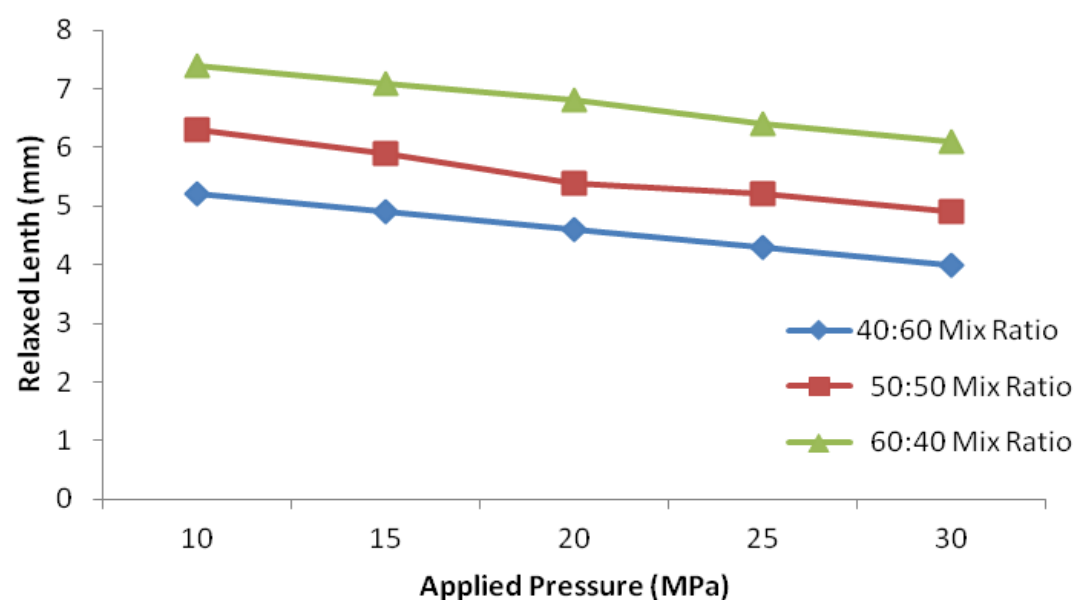

Figure 11: Graph of Applied Various Pressures Against Relaxed or Spring Back Lengths for Given Mix Ratios for Rice Straw

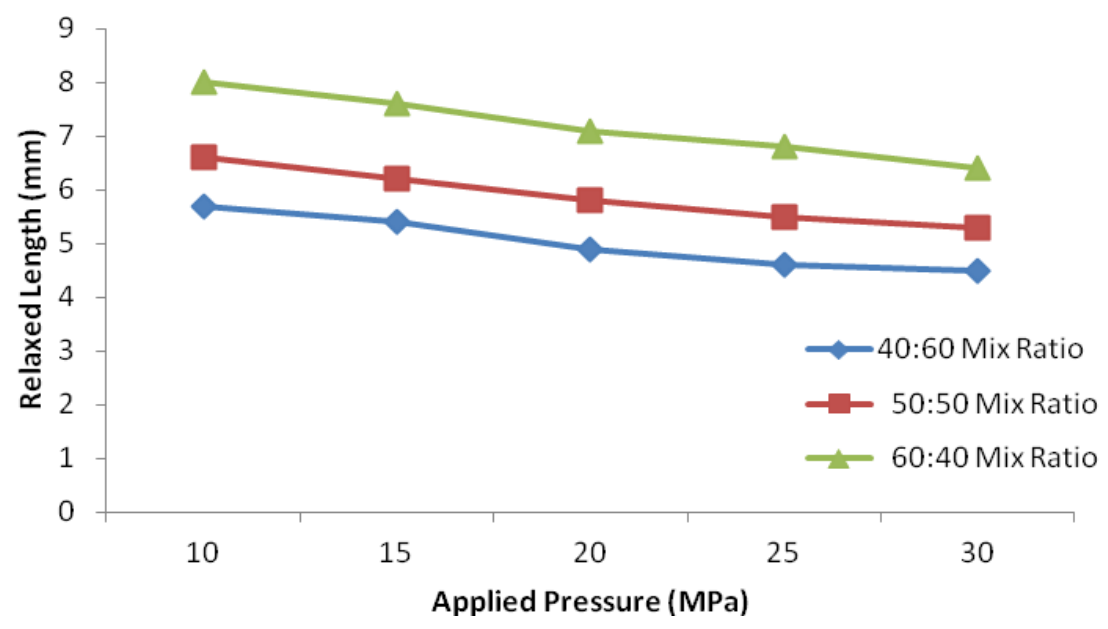

Figure 12: Graph of Applied Various Pressures Against Relaxed or Spring Back Lengths for Given Mix Ratios for Sorghum Residues 
Applied Pressures and Final Compaction Lengths for Given Mix Ratios of Briquettes Formed

Figures 13- 19 show the effect of applied pressures on the final compaction length for given mix ratio after removal from the mould. The trends of curves exhibited by the set of curves are relatively the same. The final compaction length tends to reduce at higher compressive pressure. Also, comparing base on the mix ratio, samples with 40:60 (Material: binder) revealed a low final compaction length. The final compaction length depends on the applied pressure and the nature of the material.

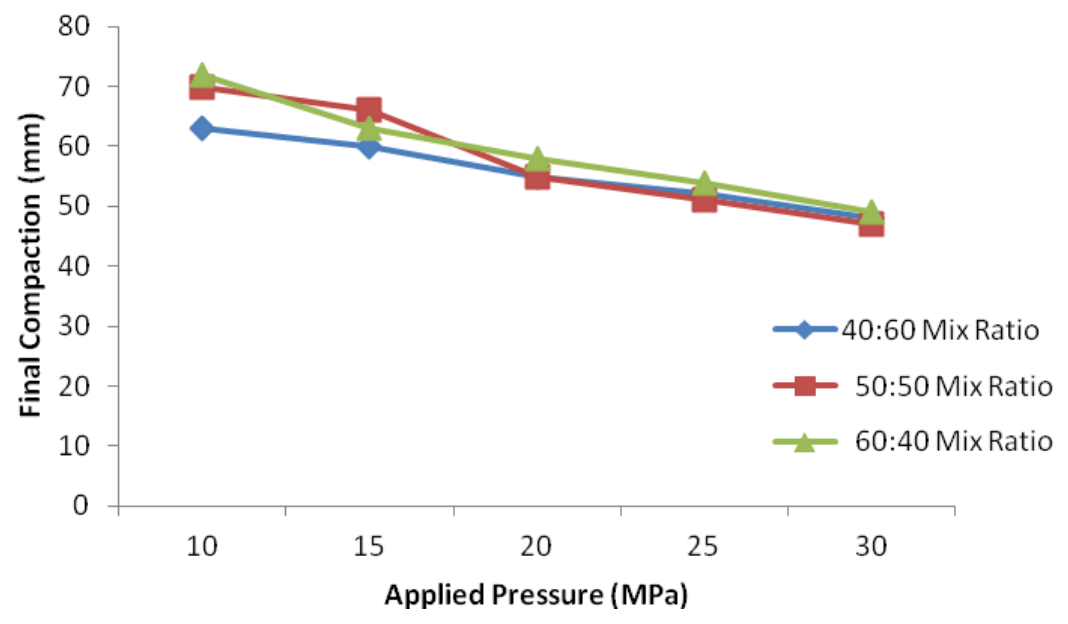

Figure 13: Graph of Applied Pressures Against Final Compaction Length of Briquette Formed for Rice Husk

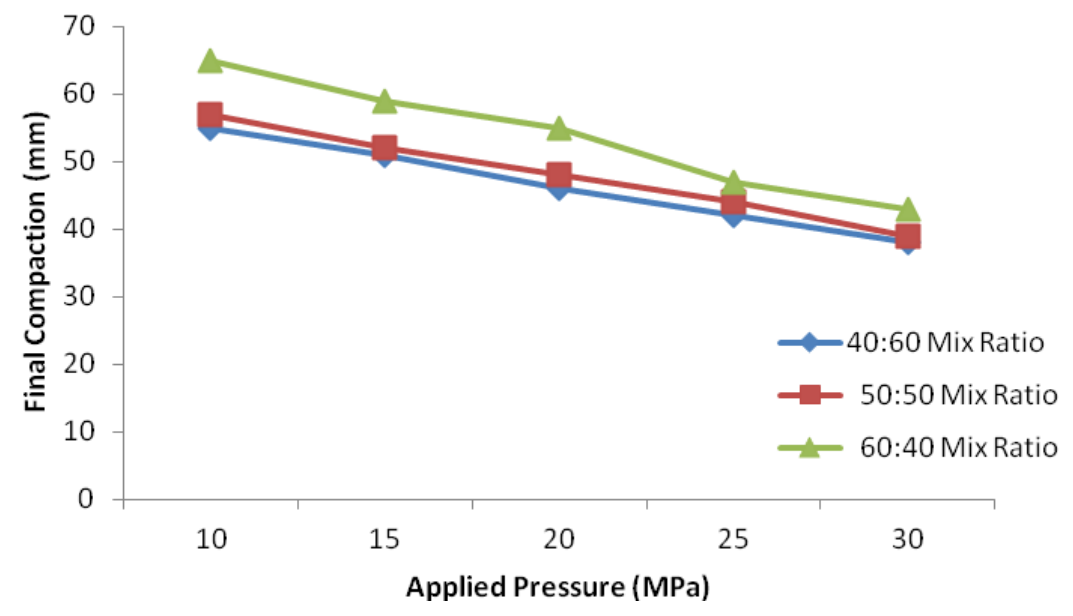

Figure 14: Graph of Applied Pressures Against Final Compaction Length of Briquette Formed for Saw Dust 


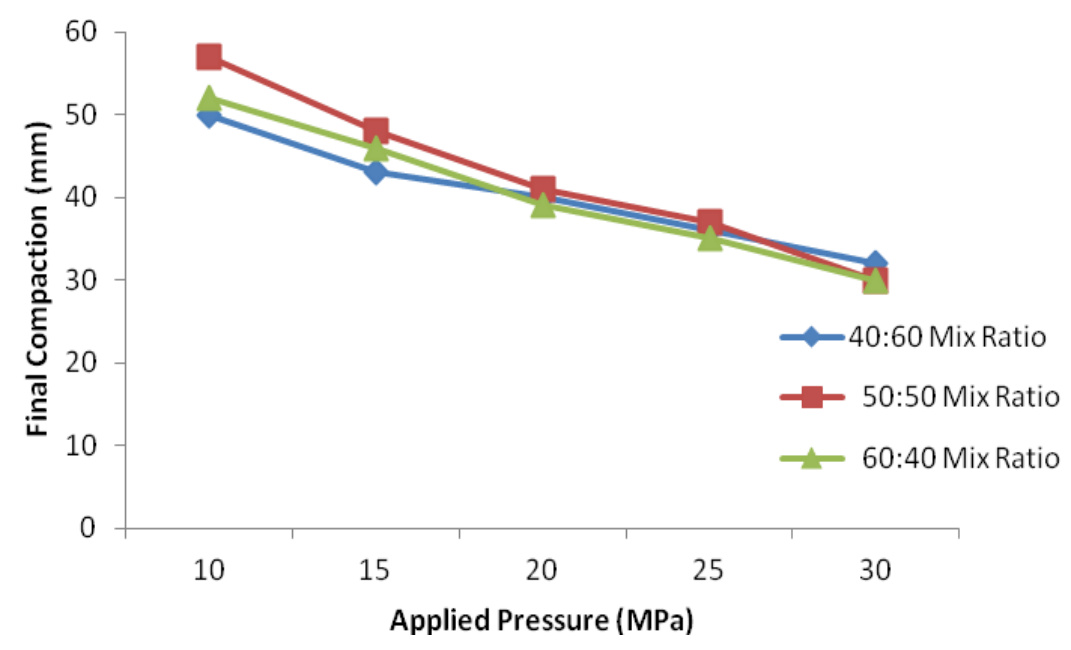

Figure 15: Graph of Applied Pressures Against Final Compaction Length of Briquette Formed for Soya Bean Residues

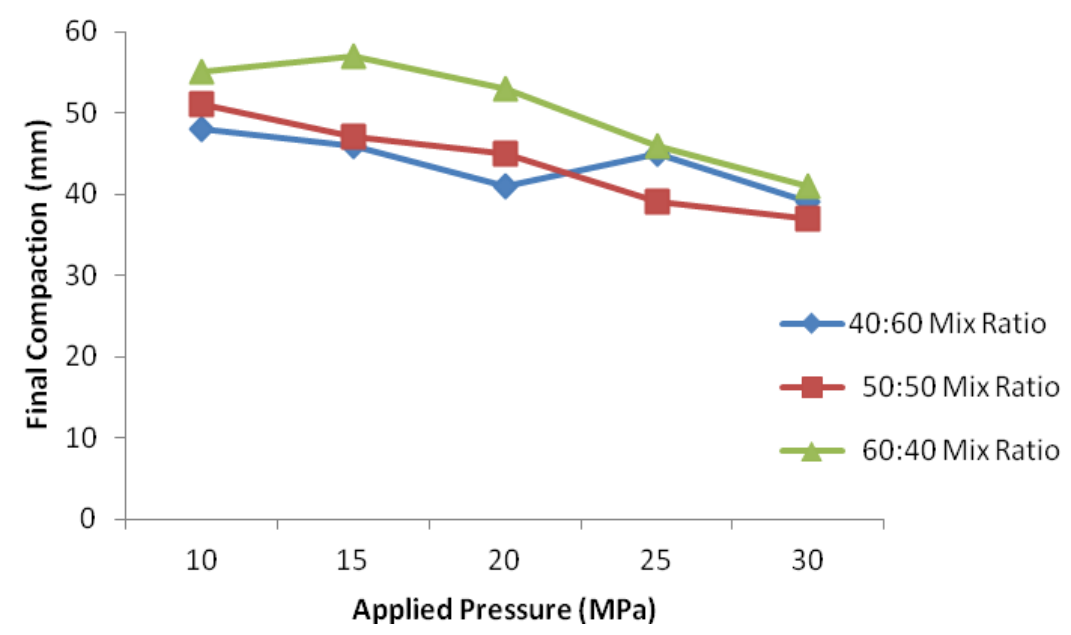

Figure 16: Graph Of Applied Pressures Against Final Compaction Length Of Briquette Formed For Sugar Cane Bagasses

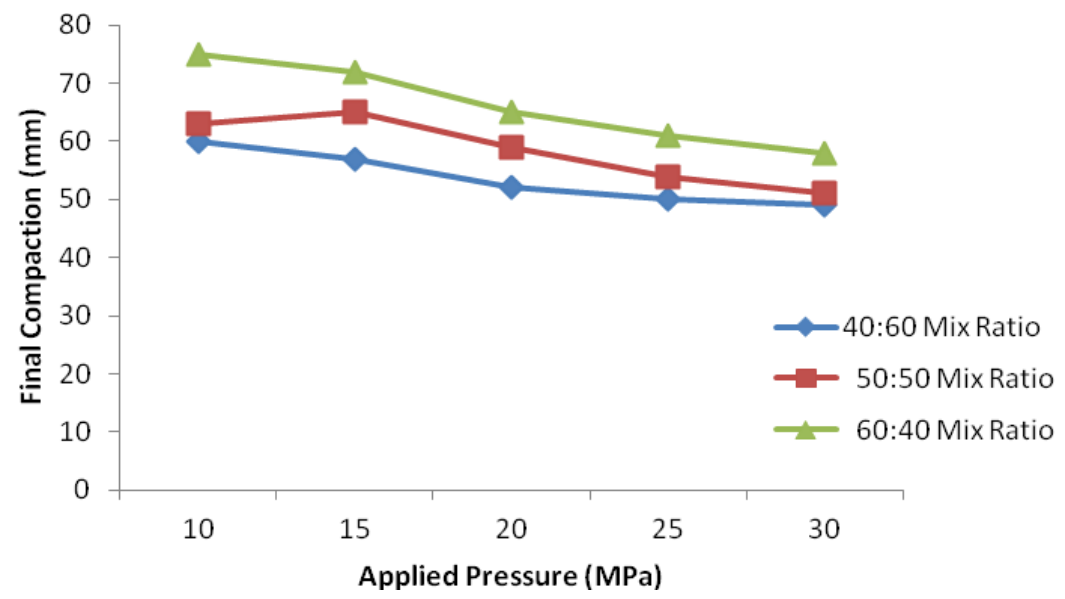

Figure 17: Graph of Applied Pressures Against Final Compaction Length of Briquette Formed for Maize $\mathrm{Cob}$ 


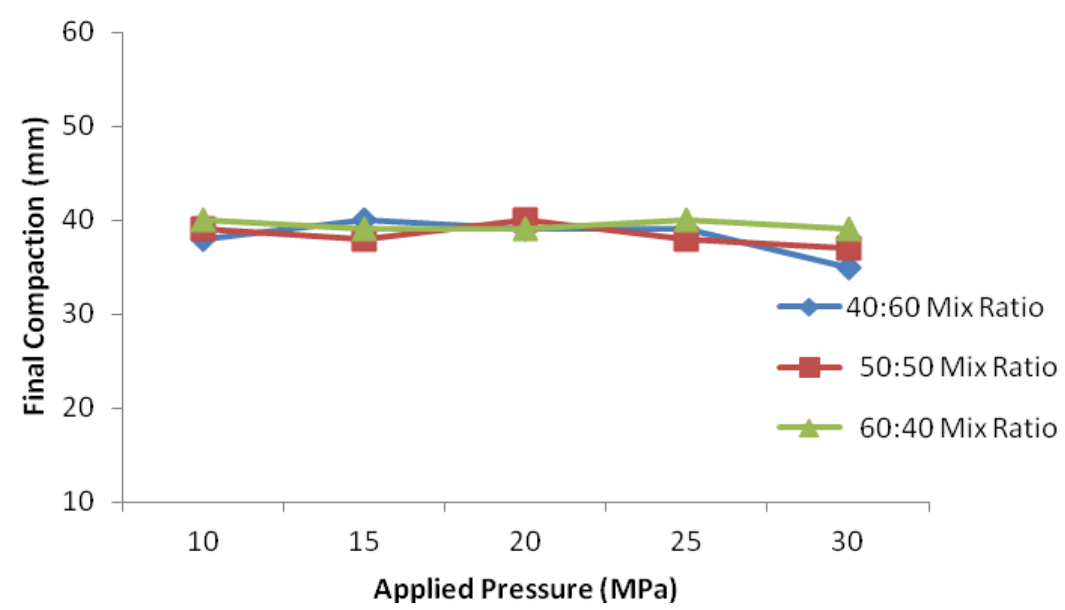

Figure 18: Graph of Applied Pressures Against Final Compaction Length of Briquette Formed for Rice Straw

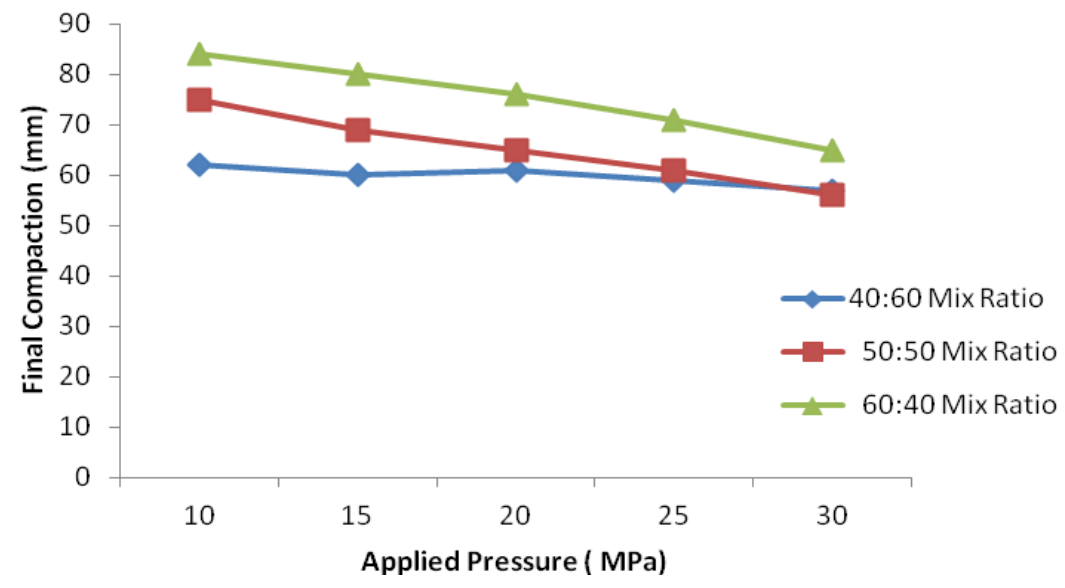

Figure 19: Graph of Applied Pressures Against Final Compaction Length of Briquette Formed for Sorghum Residue

\section{Conclusions}

Factors that influence briquetting of some agricultural wastes were examined using starch as binder. The investigation involved the determination of some physical properties, such as moisture content, bulk density and size distribution. The construction and testing of briquettes apparatus for making sample briquettes and tumbling formed was carried out so as to evaluate their characteristics and mechanical performance.

It was observed that the mix ratio has a significant influence on the briquette form and a highest durability of $89.97 \%$ was observed for saw dust at $25 \mathrm{MPa}$ using a mix ratio of 40: 60 (Material: Binder) and least was $37.30 \%$ for sorghum residues, mix ratio 60:40 at $10 \mathrm{MPa}$. The relaxed and final compaction lengths of the briquettes also depend on the mix ratio, applied pressure and nature of the material.

\section{Reference}

Abila, N. (2009). Bio-economic and Environmental Modeling of Biofuels Adoption in the Petroleum Sector in Nigeria. Department of Production, University of Vaasa, Finland. 
Koopmans, A., and Koppejan, J. (1997). Agricultural and Forest Residues: Generation, Utilization and Availability." Paper presented at the Regional Consultation on Modern Applications of Biomass Energy, January 6-10, Kuala Lumpur. http://www.rwedp.org/acrobat/p_resid ues.pdf. Accessed December 10, 2011.

Olaoye, J.O. (2001). Utilization of Biomass Resources as Renewable Energy in Nigeria. Proceedings of the 2nd International Conference \& 23rd Annual General Meeting of the Nigerian Institution of Agricultural Engineers (A division of NSE); 23: 457 - 462. Published by NIAE

Olaoye, J.O., Alonge, A.F. and Adams, B.A. (2003). Effects of Die Diameter, Mix Ratio and Compressive Force on the Briquetting of Oil Palm Mush. Nigerian Journal of Technological Development, 3: 27-37.

Oyejola, B.A. (2003). Design and Analysis of Experiments for Biology and Agriculture Students. OLAD publishers, Ilorin. Pp 29- 172.

Sambo, A.S. and Doyle, M.D.C. (1986). Estimation of the Global and Diffuse Components of Solar radiation for
Some Nigerian Cities, Nigerian Journal of Solar Energy, 5: 16 - 24. Sambo, A.S. (2009). The Place of Renewable Energy in the Nigerian Energy Sector. Presented at the World Future Council Workshop on Renewable Energy Policies, 10th October, 2009, Addis Ababa, Ethiopia.

Shah, J.K., Schultz, T.J. and Daiga, V.R. (1989). Pyrolysis Process. Section 8.7 in Standard Handbook of Hazardous Waste Treatment and Disposal, ed. H.M. Freeman. McGraw- Hill Book Company, New York, N.Y.

USDA. (2010). National Agricultural Statistics Service, http://www.nass.usda.gov/Data_and Statistics. Accessed January 14, 2012. Vimal, O.P. (1979). Residue Utilization, Management of Agricultural and Agroindustrial Residues of Selected Tropical Crops (Indian experience), Proceedings of UNEP/ESCAP/FAO Workshop on Agricultural and Agro industrial Residue Utilization in Asia and Pacific Region.

Waelti, H. and Dobie, J.B. (1973). Culpabilility of Rice Straw as Affected by Various Binders. Trans of ASAE., 16(2): 380-383. 